\title{
Dangerous Dissent? Critical Pedagogy and the Case of Israeli Apartheid Week
}

\author{
Evelyn Hamdon \\ University of Alberta \\ ehamdon@ualberta.ca \\ Scott Harris \\ Independent researcher \\ scottgharris@gmail.com
}

\begin{abstract}
This paper constitutes an examination of what is perceived to be a backlash with respect to Israeli Apartheid Week (IAW) and similar educational campaigns. In it we review recent writings which relate to the importance of critical pedagogical spaces, and which problematize the emerging pushback against popular and political educational efforts to critique the occupation of Palestine. We also examine the history of IAW and chronicle attempts (within the Canadian context) to silence organizers and teachers associated with IAW. Finally we discuss the implications of this for further organizing and teaching about Palestine. Some of the questions at the heart of this paper are, "Why is this form of social justice education perceived to be so dangerous?", "Where is the impetus coming from to silence this form of popular education" and "What are the implications of these types of surveillance and silencing."
\end{abstract}

Canadian university students and faculty have perhaps taken for granted the right to critique the hegemony of neoliberalism. However, as the year 2010 draws to close, examples of efforts to suppress forms of critical pedagogy and popular education in Canada on university campuses are unfortunately on the rise. For example, on September 17, 2010 G20 activist Alex Hundert (who was at the time living under restrictive bail conditions that did not include a ban on teaching) was arrested for participating in a panel discussion held on the Ryerson University campus. His crime was that of offering a critical analysis of G20 economic policies and the actions of Canadian police during G20 demonstrations. The purported cause for his re-arrest was that he breached the conditions of his bail, which included "non-participation in public demonstrations." 1 The broader question is not whether or not Hundert participated in a demonstration, but whether to publicly teach against hegemony ought to be constituted as a dangerous act punishable under the law.

\footnotetext{
${ }^{1}$ http://www.rabble.ca/blogs/bloggers/statica/2010/09/g8g20-communiqu\%C3\%A9-re-arrest-alex-hundert\%E2\%80\%93-why-police-should-be-charge, retrieved October 17, 2010.
} 
While the Hundert case is, we would argue, part of a wider exercise in suppressing dissent on Canadian campuses, the focus of this paper is the case involving recent attempts to silence public pedagogical efforts to critique the treatment of Palestinians under Israeli occupation. Solidarity work in the form of critical pedagogy (seminars, lectures, films and so forth) with respect to Palestine and Palestinians has always engendered heated criticism relating the substance of Palestinian claims of injustice and illegal occupation of their land. While energetic engagement with these sorts of issues are, we would argue, part of any healthy dialogue, what is in many respects shocking about interventions into Israeli Apartheid Week (IAW) activities is that it reflects surveillance and suppression of dissent rather than counter critiques of the substance of the criticisms. Secondly, it is the concerted effort of members of the public at large, university administrations and Canadian politicians to foreclose the possibility of dissent that we oppose and address through an examination of pushback against IAW on Canadian university campuses.

This paper specifically examines recent efforts to curtail or cancel Israeli Apartheid Week (IAW) events on Canadian university campuses and the struggle of educators and organizers to protect critical pedagogical spaces which might foster "autonomy, critical thought, and a substantive democracy" (Giroux \& Giroux, 2006, p. 21). Drawing upon some recent writing relating to the importance of making space (both in the literal sense as well as intellectually) for critical pedagogy, and which problematizes the emerging pushback against popular and political educational efforts both in general and with respect to the occupation of Palestine, we review recent attempts in Canada to silence those teaching at or organizing IAW events. We do this to think through the implications of this particular form of surveillance and control for other forms of activism and critical pedagogy. Some of the questions at the heart of this paper are:

- Why is this form of social justice education perceived to be so dangerous?

- Where is the impetus coming from to silence this form of popular education?

- What are the implications of politicians and university administrators curtailing activists' 'freedom to teach' on university campuses?

\section{Critical Pedagogy, Dissent, Democracy and the Academy}

Critical pedagogy is a profoundly political activity in which teachers and learners engage in collective praxis - that is reflection upon a social or political problem, analysis of the conditions which give rise to it and political action to address it (Freire, 2000). It is intended to disrupt, to interrupt and to re-imagine social and political relations - to both denounce what is and to announce what might become (Freire, 2004). It is, as Freire has written, a pedagogy of indignation (ibid.). While often relegated to the margins, critical forms of education have held an important place within Canadian adult educational history - both within and outside of university campuses (Collins, 1998; Grace, 1998; Selman et. al., 1998; Spencer, 1998), and provide the theoretical foundation for anti-oppressive educational practices (Kamishiro, 2000).

Critical pedagogy, dissent and the university have had a long relationship, indeed as Giroux (2006), Said (1994) and Kincheloe (2008) remind us, universities have traditionally resisted being a places of purely instrumental education and have historically remained a space within which dissent and critique were relatively safe from censure. Jensen (2004) points out that 
the academy has a responsibility to be intentional in providing space for the free exchange of "information, analysis and engagement" (p. 47). In these ways universities have contributed to the democratic well being of Canada (and the United States), by ensuring that contestation and dissent are not only permitted but also encouraged.

The notion of the university as a sanctuary for academic freedom has not been without its detractors. ${ }^{2}$ Over the past 50 years, roughly since the McCarthy era, concerted efforts to curtail or foreclose robust critiques of neoliberal and neoconservative economic and social issues have resulted in spaces for dissent and critique becoming more emaciated and less protected. Indeed, universities (both in Canada and the United States) appear to becoming increasingly dangerous spaces for dissenting scholars and students (Beinin, 2004; Bruneau \& Turk, 2004; Giroux, 2006; Lemberg, 2010). The rise of neoliberalism, with its corresponding effects on civil society and higher education, have seen spaces for dissent, which have traditionally been protected by governments (and here we are speaking of western governments such as the government of Canada), come under attack by those very same governments. ${ }^{3}$ With respect to universities, Giroux (2006) has written extensively about the erosion of freedom of speech on American campuses saying that

Underlying recent attacks on the university is an attempt not merely to counter dissent but to destroy it and in doing so to eliminate all of those remaining public spaces, spheres, and institutions that nourish and sustain a democratic civil society. (pp. 2-3)

Within a strictly Canadian context the recent book edited by Keefer (2010) draws our attention to increased political intervention into what can and cannot be discussed on Canadian campuses with respect to the issue of Palestine.

It is our contention that Israeli Apartheid Week (which is largely pedagogical in nature) has garnered undue political and administrative attention because it is construed as a critique of neoliberal foreign policies, particularly with respect to the issue of Israel and Palestine. In the following description of the case of IAW we wish to emphasize that the substantive issues of the critiques of the Israeli occupation of Palestine are rarely engaged with. But rather political, community and university administration's efforts to silence IAW organizers and participants is more closely related to the kinds of systematic silencing of dissent that Said, Giroux, Beinin and Lemberg have written about. In what follows it becomes clear that it is rarely the content of films

\footnotetext{
${ }^{2}$ Giroux has written an extensive history of this in his paper, Academic Freedom under Fire: A Case for Critical Pedagogy.

${ }^{3}$ It should be noted that not only universities, but other aspects of civil society are also being restricted. Non Governmental Organizations (NGOs) and grassroots organizations (GROs) of late have been censured in various ways. For example, in Canada NGOs can lose their funding if they stray too deeply into political/advocacy work on behalf of their clients (Scott, 2003). While not directly funded by universities or governments, GROs (such as Palestine solidarity groups) still require space within which to meet, organize and teach. If they cannot easily access what have been viewed as public spaces (such as universities, public libraries, NGO offices) this will have an impact on the reach and scope of their pedagogical practices.
} 
or lectures or dialogues that are censured. Rather, the focus of censorship and (fore)closure is on the very possibility for a critical perspective or a critical pedagogy: the possibility of engaging in careful political analysis, starting with the lived realities of Palestinians (both in the Middle East and in the Diaspora), that is being denied.

\section{The Case of Israeli Apartheid Week (IAW)}

For the past two years the authors of this paper have participated in the organizing of IAW events at the University of Alberta in Edmonton, Alberta, Canada. During both the 2009 and 2010 events we were struck by our university administration's (seemingly) disproportionate interest in monitoring the logistics and sometimes the content of the events. After the controversy surrounding the Mapping Models conference held at York University ${ }^{4}$ those of us involved in Palestine solidarity work became much more conscious of an apparently growing and concerted effort to constrain or even silence popular educational events which either support a free Palestine or which critique the illegal Israeli occupation of Palestine.

\section{History of IAW}

Israeli Apartheid Week (IAW) ${ }^{5}$ was conceived as a way to broaden public awareness of the lived and political realities of Palestinians. The inaugural Israeli Apartheid Week was organized in 2005 by students at the University of Toronto in response to the United Palestinian Call for Boycott, Divestment and Sanctions (BDS). ${ }^{6}$ Since the first IAW, the annual event has spread to cities and campuses around the world, with 56 cities participating in the 2010 iteration, including cities in Europe, South Africa, South America, as well as, notably, within Israel as well as both Gaza and the West Bank.

${ }^{4}$ In 2009 the Faculty of Law at York University hosted an international conference called Mapping Models of Statehood and Paths to Peace. On the conference website (http://www.yorku.ca/ipconf/) the stated purpose of the conference was to seek to "systematically measure models based on two states or a single binational state, federal and con-federal approaches, and other models in between and beyond". The conference framework was designed to allow for "robust academic critiques of various proposals and to allow space for a scholarly engagement with the issues". Despite this careful planning, the organizers of the conference faced intense pressure (both political and from within some parts of the Canadian Jewish community). An example of this pressure includes a call from the Jewish Defense League (in the form of a petition to the parliament of Canada) to revoke the conference's Social Sciences and Humanities Research Council (SSHRC) funding.

${ }^{5}$ As the name suggests, IAW is organized within a framework that situates the policies of the State of Israel as meeting the international definition of apartheid, as defined by the United Nations in the International Convention on the Suppression and Punishment of the Crime of Apartheid, which came into force in 1976 and has been ratified by 107 states, and the Rome Statute of the International Criminal Court, which defines apartheid as a crime against humanity. http://apartheidweek.org/, retrieved October 14, 2010.

${ }^{6}$ The BDS call was issued on July 9, 2005, the first anniversary of the International Court of Justice advisory opinion which declared that the construction by Israel of its wall/security barrier in the Occupied Palestinian Territories is illegal, and called on Israel to dismantle the wall and pay reparation to those who have suffered as a result of its construction.

${ }^{7}$ http://apartheidweek.org/, retrieved October 14, 2010. 
While there is some centralized coordination of IAW events, including the clearinghouse apartheidweek.org website and shared graphical elements and promotional material and coordination of speaker tours either nationally or regionally, individual cities have considerable latitude in the specifics of the events, within the framework of the three core demands of the BDS call. Activities are planned by local grassroots groups and often comprised of a combination of students and community members. Primarily an educational campaign, IAW events typically involve film screenings, lectures, cultural events and protests, often linking the elements of Israeli apartheid to other issues of social justice, Indigenous solidarity movements, and, increasingly as IAW has been targeted by Zionist and pro-Israel groups, issues of censorship, free speech and academic freedom.

Over the past three years, as more Canadian cities have begun to organize Israeli Apartheid Week events -13 Canadian cities formally took part in 2010 - there have been increasing efforts by organizations such as B'nai Brith Canada, campus-based Hillel student groups, the Canada Israel Committee, Canadian Jewish Congress, and the Jewish Defense League to pressure universities to censor or prevent IAW events from taking place. Canadian politicians at all levels of government have also brought forward resolutions condemning IAW, picking up the narrative of IAW as "hate-fests" that promote a "new anti-Semitism" and lead to emotional or actual physical harassment of Jewish students on campuses where IAW events are organized.

Most successful attempts to censor or censure IAW events have occurred on campuses in Ontario, but in addition to city-specific efforts there have also been a number of national antiIAW initiatives launched with varying degrees of success over the past two years. Censorship has taken the form of national calls for outright cancellation of IAW events, ${ }^{8}$ attempts at banning promotional and public relations materials and punishment for and attempts to prevent events taking place on university campuses. In addition to these efforts by pro-Israel lobby groups, some academics have also engaged in concerted attempts to silence dissent and debate on the question of Palestine. ${ }^{9}$ Perhaps most alarming is the involvement or support of politicians in the campaigns to silence dissident voices and to interfere with academic freedom on Canadian university campuses.

\footnotetext{
${ }^{8}$ In the lead up to IAW 2009 B'nai Brith took out a series of three ads in the National Post on February 14, February 21 and March 7 as part of its effort to pressure university administrators to prevent IAW events from taking place on Canadian campuses. This information can be found on the B'nai Brith website at http://www.bnaibrith.ca/files/20090217.pdf, retrieved October 14, 2010.
}

\footnotetext{
${ }^{9}$ For example, on March 22, 2008125 University of Toronto faculty members placed a full-page ad in the National Post which read, "We, the undersigned faculty members of the University of Toronto, oppose the hosting of the Israeli Apartheid Week at our Institution, and request that the administration stop this hateful and divisive event from returning to our University in future years." On April 2, 2008 the formation of the Toronto Chapter of Scholars for Peace in the Middle East was announced, "in response to the annual hosting of IAW on our campus," and claimed responsibility for the ad. http://spme.net/cgi-bin/articles.cgi?ID=3832, retrieved October 142010.
} 


\section{Censorship of IAW Promotional Materials}

In the lead-up to IAW 2008 at Hamilton's McMaster University the student group Solidarity for Palestinian Human Rights (SPHR) was prevented by the university's Human Rights and Equity Services office and the McMaster Students Union (MSU) from hanging in the university's student centre a banner containing the words "Israeli apartheid." ${ }^{10}$ An email from the Human Rights and Equity services to SPHR explained that

The university has taken the position that literature which refers to 'Israeli apartheid' and activities promoted under the banner, 'Israeli Apartheid Week' are unacceptable. The university takes the position that this phrase is in violation of the university's efforts to ensure that all people will be treated with dignity and tolerance.

McMaster Provost Dr. Ilene Busch-Vishniac supported the decision. ${ }^{11}$

Carlton University Provost Feridun Hamdullahpur ${ }^{12}$ similarly supported a ban on promotional materials based on text or images they claimed some members of the community found offensive, namely a poster designed by the Brazilian cartoonist Carlos Latuff, depicting a helicopter labeled "Israel" firing a rocket at a child wearing a keffiyeh with a shadow spelling "Gaza". Ottawa University's communications office also banned the same poster, writing to the student group Solidarity for Palestinian Human Rights that

All posters approved by the Communications Office must promote a campus culture where all members of the community can play a part in a declaration of human rights recognizing the inherent dignity and equal rights of all students. Consequently, we will not place this particular poster on our campus billboards. ${ }^{13}$

The charge that it violated human rights was never substantiated leaving in doubt the validity of the charge.

\section{Space for Critical Pedagogy?}

\footnotetext{
${ }^{10}$ http://www.cjnews.com/index.php?option=com_content\&task=view\&id=14170\&Itemid=101, retrieved October $14,2010$.

${ }^{11}$ Dr. Busch- Vishniac writing in a February 21 email to SPHR, called the banner "highly inflammatory." For a summary of this issue see http://www.macinsiders.com/showthread.php/israeli-apartheid-controversy17887.html?s=aab8f9e9615dd9a9757c7f3601e56b90\&amp;t=17887, retrieved October 14, 2010.
}

${ }^{12}$ In 2009, Carleton's equity services ordered posters removed from campus on the basis that they "could incite infringements of the Ontario Human Rights code." For more details on this see also:

http://sphrottawa.blogspot.com/search/label/Apartheid\%20Week, retrieved October 14, 2010.

${ }^{13}$ http://sphrottawa.blogspot.com/2009/02/urgent-iaw-posters-banned-on-campus.html, retrieved March 3, 2011. 
Perhaps one of the most widespread ways in which IAW activities were and are thwarted is by denying space or insisting on adherence to logistical procedures that are extraordinary thereby hindering or stopping activities. There are a number of examples of intentional prevention and punishment of IAW and other pro-Palestinian events on campuses, often justified by reference to student codes of conduct or regulations relating to room bookings or the use of sound amplification devices. Policies and regulations appear to have been used very specifically to target IAW events. On February 24, 2009, just a week before IAW events were scheduled to begin, York University's Students Against Israeli Apartheid (SAIA@York) was notified by York University Administration that its club status had been suspended for the next 30 days and that the group was being handed $\$ 1250$ in group and individual fines after the group "actively participated in a rally in Vari Hall on February 12, using various sound amplification devices and other noise making instruments," which the administration claims disrupted classes. In May of 2008, York political science professor David McNally received a disciplinary letter from his dean for similarly speaking "by means of amplification" at "an unauthorized student rally" in support of Palestine, despite having spoken the previous day on another issue at the same location without censure. ${ }^{14}$

One of the most egregious and well-documented examples of a university administration intentionally using campus rules to prevent pro-Palestinian activities on university campuses was revealed following a freedom of information (FIPPA) request following the denial by York University to allow the group Students Against Israeli Apartheid (SAIA) from holding an October 2008 conference entitled "Standing Against Apartheid: Building Cross-Campus Solidarity with Palestine." A series of emails released through FIPPA - over 250 pages in less than a week - reveal that individuals up to and including University of Toronto President David Naylor were involved in correspondence regarding how best to deny SAIA's request for space to hold the conference, and from whom the message should come to make it look most legitimate all before the group had even made a formal room booking request. ${ }^{15}$ What is revealed in the emails between university administration and those outside of the academy is a concerted attempt to prevent critical pedagogical engagement with the issue of Palestine. In one email, McMaster University Associate Vice President Phil Wood refers to "the type of war fare [sic] that seems to exist in Toronto" and writes to Jim Delaney, director of York's Office of the ViceProvost, that " ... we would certainly appreciate any intel that you can provide us regarding the meeting this weekend and plans fr [sic] IAW." "In his email Wood also writes, "In any case we are already starting to plan for a potential Israeli Apartheid Week in March. In fact our Crisis Management Group meets tomorrow and I will also be meeting with our new Director of Human Rights and Equity and our Director of Public Relations." ${ }^{17}$ A response sent to Wood and Delaney

\footnotetext{
Report-Israel-lobby-York-University-2008, retrieved March 3, 2011.

${ }^{15}$ Exposed: University of Toronto Suppressed Pro-Palestinian Activism, Lisa Schofield, http://www.socialistproject.ca/bullet/bullet188.html, retrieved March 2, 2011.

${ }^{16}$ Ibid

${ }^{17}$ Ibid
}

${ }^{14}$ For details of these cases and others, see CAUT's Report of the Ad Hoc Investigatory Committee on Freedom of Speech, Academic Freedom and Governance at York University, available at http://www.archive.org/details/CAUT- 
from McMaster Director of Security Terry Sullivan reads, "We will certainly be calling on our friends in other universities to put together plans/strategies for March 2009 when I think they intend on doing protest weeks throughout the university landscapes." 18

Such high-level coordination suggests that more than merely the innocuous enforcement of student code of conduct and room booking rules, administrators at the highest levels of major Canadians universities view the dissent expressed by Palestinian activists as significant enough to warrant coordinated strategies and responses on a regional level. It is this apparently intentional closing down of space on campuses for dissenting perspectives that provides evidence for Giroux and Beinin's claims that these actions reflects a particular ideological position. Since none of the claims of hate speech were ever proven, the actions on the part of administration seem intended to stop the very airing of an alternative perspective on Israel/Palestine. Which begs our original question, why would this be so dangerous?

The actions described above which stem from a particular ideological position are further exacerbated by the already-described pressure exerted by pro-Israel lobby groups, but also by more troubling external public pressure applied or attempted by elected offices, representing all major political parties in Canada and at every level of government. The interplay between the political class and academia in reinforcing this ideological bias should not be underestimated. For instance, Liberal Leader Michael Ignatieff spent many years as an academic in the United States and later at the University of Toronto, and University of Winnipeg President Lloyd Axworthy is the former Minister of Foreign Affairs in the Chretien government.

\section{Political Condemnation}

Beginning with the high profile garnered by the 2009 IAW, which came less than two months after Israel carried out "Operation Cast Lead," and which led to the death of an estimated 1400 Gazans, including some 300 children, ${ }^{19}$ a number of initiatives were launched by Canadian politicians to condemn IAW, commonly framing IAW as tantamount to hate speech and an example of a troubling "new anti-Semitism."

On March 3, 2009, Conservative MP Paul Calandra (Oak Ridges-Markham) claimed "Jewish students across the country are under siege as anti-Semites unveil their plans for Israel Apartheid Week" and his fellow Conservative Minister of Citizenship, Immigration and Multiculturalism Jason Kenney characterized IAW as

a systematic effort to delegitimize the democratic homeland of the Jewish people, a country born out of the Holocaust. We find very troubling this

\footnotetext{
${ }^{18}$ Ibid

19 "B'Tselem's investigation of fatalities in Operation Cast Lead". B'Tselem. September 9, 2009. http://www.webcitation.org/5niCUh4K4. Retrieved September 22, 2010.
} 
resurgence of the old slander that Zionism is racism. That is the notion that lies at the heart of Israel Apartheid Week."20

In the same Parliamentary session Liberal MP for Eglington-Lawrence Joe Volpe said that IAW events "sow discord, promote negative stereotyping and fuel hatred," and charged "The safety and security of Jewish students and their instructors will be unnecessarily placed in danger by these demonstrations." Volpe concluded by calling for "university administrations to take steps to stop anti-Semitism and the dissemination of hatred." 21

On March 4, 2009 Canadian Senator Yoine Goldstein rose during the time allotted for senators' statements and condemned what she called "a distressing series of events in Canada that are reminiscent of darker chapters in world history." 22 Goldstein referred to IAW events as "an anti-Semitic frenzy." 23

In the National Post's Full Comment section of the same day, Liberal Leader Michael Ignatieff charged "IAW goes beyond reasonable criticism into demonization. It leaves Jewish and Israeli students wary of expressing their opinions, for fear of intimidation." ${ }^{24}$ It is interesting to note that the Jewish Tribune reported that prior to Ignatieff"s op-ed appearing, "A private meeting had been held earlier between B'nai Brith Canada leaders and the Liberal leader, in which these same concerns were raised." 25

Condemnation from the political arena increased in advance of the 2010 IAW events. On February 25, 2010 the Ontario Legislature unanimously passed a motion brought forward by Progressive Conservative MPP for Thornhill Peter Kent "that in the opinion of this House, the term 'Israel Apartheid Week' is condemned as it serves to incite hatred against Israel." ${ }^{26}$ In speaking to his motion, Sherman stated, "The use of the phrase 'Israeli Apartheid Week' is about as close to hate speech as one can get without being arrested, and I'm not certain it doesn't actually cross over that line." 27 While only 30 members of the 107-seat legislature were present

20

http://www2.parl.gc.ca/HousePublications/Publication.aspx?DocId=3714890\&Language=E\&Mode=1\&Parl=40\&Se $\underline{\mathrm{s}=2}$

${ }^{21}$ Ibid

${ }^{22}$ Debates of the Senate (Hansard), 2nd Session, 40th Parliament, Volume 146, Issue 15, Wednesday, March 4, 2009, http://www.parl.gc.ca/40/2/parlbus/chambus/senate/deb-e/015db_2009-03-04-

E.htm?Language=E\&Parl=40\&Ses=2\#9, retrieved September 21, 2010.

${ }^{23}$ Ibid

${ }^{24}$ http://network.nationalpost.com/np/blogs/fullcomment/archive/2009/03/05/michael-ignatieff-israel-apartheidweek-and-cupe-ontario-s-anti-israel-posturing-should-be-condemned.aspx\#ixzz10EUA5M1X

${ }^{25}$ http://www.jewishtribune.ca/TribuneV2/index.php/200903101451/Liberals-join-Conservatives-condemn-IAWCUPE-resolution-but-no-specific-NDP-policy.html

${ }^{26}$ http://cija.ca/en/media/ontario-legislature-unanimously-condemn-israel-apartheid-week/

${ }^{27}$ Ibid 
for the unanimous vote ${ }^{28}$ MPPS from all three political parties spoke to and voted for the motion, though Ontario NDP leader Andrea Howarth, who was not present for the vote, later attempted to distance her party from the motion." 29

Federal Liberal Leader Michael Ignatieff issued an official statement similarly condemning IAW, charging, “ ... Israeli Apartheid Week will once again attempt to demonize and undermine the legitimacy of the Jewish state. It is part of a global campaign of calls for divestment, boycotts and proclamations, and it should be condemned unequivocally and absolutely." ${ }^{, 30}$ While failing to point to specific examples, Ignatieff's statement goes on to charge, "Jewish and Israeli students ... will be made to feel ostracized and even physically threatened in the very place where freedom should be paramount -- on a university campus." 31

On March 11, 2010, Conservative MP for Edmonton-Sherwood Park Tim Uppal introduced a motion in the House of Commons stating, "That this House condemns Israeli Apartheid Week for seeking to delegitimize the State of Israel by equating it with the racist South African apartheid regime." 32 The motion did not receive the unanimous consent required, and was not approved by Parliament.

On April 15, 2010 Manitoba Conservative MLA Heather Stefanson introduced an unsuccessful motion charging that "Israeli Apartheid Week may promote anti-Semitic opinions leading to the harassment and intimidation of Jewish students and staff." 33

\section{In Defence of Dissent}

In response to the various efforts outlined above, Israeli Apartheid Week organizers and their supporters have often managed to respond successfully in the face of attempts at censorship or cancellation of events. For example, the banning of IAW posters led to campaigns encouraging pressure on university administrations to compel them to defend freedom of speech. In the case of the campaign by Students Against Israeli Apartheid, Carleton students demanded that the Carleton University administration: 1. Immediately lift the ban on the Israeli Apartheid Week poster and publicly apologize for the banning; 2. Explain, publicly and precisely, how the profound error of banning the poster was made and address how to prevent such violations from occurring in future; 3 . Sponsor a full public debate-- ensuring generous access to the entire

\footnotetext{
${ }^{28}$ http://www.thestar.com/news/article/778152

${ }^{29}$ Ibid

${ }^{30}$ http://www.liberal.ca/newsroom/news-release/statement-by-liberal-leader-michael-ignatieff-regarding-israeliapartheid-week/

31 Ibid

32

http://www2.parl.gc.ca/HousePublications/Publication.aspx $?$ Language=E $\&$ Mode=1 $\&$ Parl=40\&Ses $=3 \& D o c I d=4342$ 803

${ }^{33}$ http://www.gov.mb.ca/legislature/hansard/4th-39th/hansardpdf/29a.pdf
} 
university community-- on Carleton's position on the proposed institutional boycott of Israeli academic institutions; and 4. Appoint a university/community Commission to investigate the record of the University in relation to democratic discourse and equity around issues of Palestine solidarity. $^{34}$

In response to the motion in the Manitoba Legislature to condemn IAW, the University of Manitoba Students' Union voted overwhelmingly to pass a motion in support of free speech on the campus, resolving that "UMSU support the right of students to speak up against all systems of oppression, including apartheid," and that "UMSU oppose any attempt to infringe on students right to organize against oppression, whether these attempts to infringe on students' rights come from the state, University administrators, or other actors." 35

In addition to student responses, attempts to censor IAW events have also elicited responses from faculty members at various universities. Faculty for Palestine (F4P) issued an open letter ${ }^{36}$ signed by over 400 academics in response to what it called "increasing efforts to limit advocacy of Palestinian rights on Canadian universities, amounting to a pattern of the suppression of freedom of speech and freedom of assembly." ${ }^{37}$ The letter specifically calls for the "freedom to use the term 'apartheid' to identify and debate certain policies associated with the state of Israel and the freedom to support, facilitate and participate freely in activities under the rubric of "Israeli Apartheid Week" and "an end to the silencing of speech around Palestine, removing extraordinary requirements for security clearance and fees for security services." 38

In October of 2009 over 139 York University faculty members and 58 students signed a petition in response to claims that York University had become "a site where antisemitism is rife," 39 saying that "Concocted accounts of "violent anti-Jewish riots at York University' (in the words of the Jerusalem Post, February 15, 2009) have become widespread," 40 declaring that "The use of such inflammatory language cannot any longer be ignored and allowed to fester" 41 and that "we strongly defend our university's long-cherished mission to promote public debate, including debate on contentious political issues." 42

\footnotetext{
${ }^{34}$ http://ottawa.apartheidweek.org/node/146, retrieved October 14, 2010.

${ }^{35} \mathrm{http} / / /$ winnipeg.apartheidweek.org/, retrieved October 14, 2010.

${ }^{36} \mathrm{http} / / /$ www.caiaweb.org/committees/faculty-for-palestine/, retrieved March 3, 2011.

${ }^{37}$ Ibid

${ }^{38}$ Ibid

${ }^{39} \mathrm{http} / / / \mathrm{www}$. straight.com/article-266050/york-university-professors-and-students-reject-claims-antisemitism, retrieved October 14, 2010

${ }^{40}$ Ibid

${ }^{41}$ Ibid

${ }^{42}$ Ibid
} 
Attempts in Canada to stifle IAW have even been condemned by groups in Palestine. On May 26, 2010 the Palestinian Boycott National Committee (BNC) Secretariat issued a statement condemning "the actions taken by Canadian state bodies, university administrations and pressure groups to defund, repress and otherwise attempt to weaken groups and individuals that provide assistance to, or campaign in solidarity with, Palestinians" 43 and pointing out that "Attacks on Palestine solidarity activism have become commonplace in Canadian universities. Student and faculty groups ... have been targeted with aggressive bureaucratic delays and obstacles, the arbitrary charging of security fees, and outright banning of their activities." 44

\section{Dissent in the Age of Neo-McCarthyism}

Both Beinin (2004) and Giroux (2006) liken the current hostility towards dissent, leftwing critiques of neoliberalism, anti-colonial perspectives and anti-oppressive analysis, to a new era of McCarthyism. However, they also caution that contemporary attempts to silence dissent and punish dissenters speak to a nuanced and sophisticated understanding, on the part of neoliberals and neoconservatives, of the power of intellectual and academic freedom. That the assault on academic freedom, on the freedom to dissent (both on campuses and in other formerly more open spaces such as the media) is a form of recognition of the power of pedagogy to sustain democracy (Giroux, 2006) to challenge neoliberal structures and strictures, and to make space for multiple, contested viewpoints. In his article entitled The New McCarthyism, Beinin (2004) reveals a network of political relationships and agendas, which reflect a neoliberal and neoconservative bias. He argues that the deeply political motivations for what he has described as a sustained campaign to stifle dissent amounts to the foreclosure of rigorous dialogue and engagement with issues relating specifically to Israel and Palestine and for academic freedom in general.

This characterization of the backlash as a new form of McCarthyism is echoed by Canadian activist and anti racism educator Lynda Lemberg (2010) who writes:

It is my fear that we are on the cusp of a period characterized by a new form of McCarthyism. It is our duty as citizens of Canada to resist recent attempts to muzzle dissent and silence criticism of another nation-state by redefining our own hate laws. (p. 36)

Both Beinin and Lemberg emphasize that while hate speech should continue to be monitored and punished, what constitutes hate-speech should be carefully considered. Political critique, advocacy for human rights and solidarity with occupied Palestinians, they contend, does not, de facto, constitute hate speech.

\footnotetext{
${ }^{43} \mathrm{http}: / /$ usacbi.wordpress.com/2010/05/27/palestinian-boycott-national-committee-statement-on-repression-incanada/, retrieved October 14, 2010.

${ }^{44}$ Ibid
} 
These observations on the part of Beinin and Lemberg are congruent with the lived experiences of IAW organizers who, for the past almost three years have been surveilled and disciplined through the coordinated efforts of university administrators, politicians and what have been described as pro-Israel advocacy groups. We argue that these efforts to curtail IAW activities have implications for the place within the academy for critical forms of pedagogy.

In a recently edited volume entitled Anti-Semitism Real and Imagined (Keefer, 2010), Canadian academics and activists respond to the current political climate in which dissent and critical pedagogies are often characterized as hate speech. Keefer (2010) has documented how allegations of hate speech have served to (at least temporarily) shift the focus from a rigorous engagement with the issues. The case of IAW, we argue, is worthy of note given its pedagogical and student focus. Universities have and continue to be sites where ideas are contested and where disagreement is regarded as generative. Perhaps most importantly, universities have been sites of important human rights work, both theoretically but also with respect to educating for human rights. The precedents set during the past two years in which IAW has come under constant scrutiny, and during which organizers have been held to previously unheard of (and sometimes invented) standards ought to incite educators and activists to more carefully consider the implications of these forms of silencing.

We began this paper with a reference to the criminalization of dissent with respect to the arrests of G20 activists in Toronto, Canada in June of 2010. This was done to draw attention to the ways in which neoliberal discourse about the danger of dissent is serving to create an environment wherein the next step is potentially to try and criminalize it. IAW organizers and teachers continue to challenge their universities to protect freedom of speech, the freedom to teach and freedom to dissent. Perhaps our universities will be a beacon for the rest of the country and for our country's political leaders, reminding them and all of us that racism and anti-Semitism will not vanish within a climate of censorship and fear but with the context of careful interrogations of systems of oppression.

We have argued that the censure and censorship of IAW on Canadian university campuses is not related to the substantive issues regarding Palestine and injustices perpetrated upon Palestinians but gestures towards a wider and more longstanding assault on academic freedom and freedom of dissent. As Giroux (2006), Lemberg (2010), Beinin (2004), Said (1994), Herman (2007), Chomsky (2005), and many others have argued, a healthy democracy demands multiple sites where citizens (including academics) can engage with the substantive issues of the day without fear of reprisal or censorship. 


\section{References}

Bakan, A.B. \& Abu-Laban, Y. (2009). Palestinian resistance and international solidarity: The BDS campaign. Race and Class, 51(1), pp. 29-54. DOI: 10.1177/0306396809106162.

Beinin, J. (2004). The new American McCartthyism: Policing thought about the Middle East. Race \& Class, 56(1), pp. 101-115. DOI: 04551710.1177/0306396804045517

Bruneau, W. \& Turk, J. (2004). Disciplining dissent. The curbing of free expression in academia and the media. Toronto: James Lorimer \& Company Ltd.

Collins, G. (1998). The imaginative training for citizenship. In Selman et. al. (Eds.), Learning for life: Canadian readings in Adult Education (pp. 24 - 34). Toronto: Thompson International Publishing, Inc.

Chomsky, N. (2005). Imperial ambitions. New York: Metropolitan Books.

Freire, P. (2000). Pedagogy of the oppressed. New York: Continuum.

Freire, P. (2004). Pedagogy of indignation. Paradigm Publishers.

Giroux, H. (2003). Public pedagogy and the politics of resistance: Notes on a critical theory of educational struggle. Educational Philosophy and Theory, 35(1), pp. 5-16.

Giroux, H. (2006). Academic freedom under fire: The case for critical pedagogy. College Literature, 33(4), pp. 1-42.

Giroux, H. \& Giroux, S. S. (2006). Challenging neoliberalism's new world order: The promise of critical pedagogy. Cultural Studies $<=>$ Critical Methodologies, 6(21), pp. 21-3.

Grace, A. (1998). Parameters, pedagogy and possibilities in changing times. In Selman et. al. (Eds.), Learning for life: Canadian readings in Adult Education (pp. 114 -124). Toronto: Thompson International Publishing, Inc.

Herman, E.S. (2007). Toward a democratic media. In D. Macedo \& S. Steinberg (Eds.), Media literacy: A reader (pp. 37 - 53). New York: Peter Lang.

Jensen, R. (2004). September 11 and the failure of American intellectuals. In William Bruneau \& James L. Turk (Eds.), Disciplining dissent: The curbing of free expression in academia and the media (pp. 38 - 50). Toronto: James Lorimer and Company Ltd.

Keefer, M. (2010). Introduction. In M. Keefer (Ed.), Antisemitism real and imagined: Responses to the Canadian Parliamentary Coalition to combat antisemitism (pp. 7 - 29). Waterloo: The Canadian Challenge.

Kincheloe, J. \& Steinberg, S. (2006). An Ideology of miseducation: Countering the pedagogy of empire. In Cultural Studies $<=>$ Critical Methodologies, 6(33), pp. 33-51. DOI: $10.1177 / 1532708605282808$

Kincheloe, J. (2008). The vicissitudes of twenty-first centure critical pedagogy. Stud Philos Educ, 27, pp. 399-404. DOI 10.1007/s11217-007-9084-9

Kumashiro, K. K. (2000). Toward a theory of anti-oppressive education. Review of Educational Research, 70(1), pp. 25-53. 
Lemberg, L. (2010). Not in my name. In M. Keefer (Ed.), Antisemitism real and imagined: Responses to the Canadian Parliamentary Coalition to combat antisemitism (pp. 33 - 38). Waterloo: The Canadian Challenge.

Said, E. (1994). Representations of the intellectual. New York: Pantheon. Spencer, B. (1998). Worker's education for the twenty-first century. In Selman et. al. (Eds.), Learning for life: Canadian readings in Adult Education (pp. 164 - 175). Toronto: Thompson International Publishing, Inc. 